\title{
Location Intelligence in Cogenerated Heating Potential Data Analysis
}

\author{
Almir Karabegovic \\ University of Sarajevo, \\ Faculty of Electrical \\ Engineering, Kampus \\ Univerziteta u Sarajevu, \\ 71000 Sarajevo, BiH \\ Email: \\ akarabegovic@etf.unsa.ba
}

\author{
Mirza Ponjavic \\ International Burch \\ University, Sarajevo, \\ Francuske revolucije bb, \\ Ilidža 71210, Bosnia and \\ Herzegovina \\ Email: \\ mirza.ponjavic@gis.ba
}

\author{
Neven Duic \\ University of Zagreb, \\ Faculty of Mechanical \\ Engineering and Naval \\ Architecture, Ivana Lučića 5, \\ 10002 Zagreb, Croatia \\ Email: \\ neven.duic@fsb.hr
}

\author{
Tomislav Novosel \\ North-West Croatia \\ Regional Energy \\ Agency, Andrije Zaje \\ 10, 10000 Zagreb, \\ Croatia \\ Email: \\ tnovosel@regea.org
}

\begin{abstract}
Different methodologies are used to assess the potential for using high efficiency cogeneration for cooling and heating. They are mostly adapted to the availability of data and tools for their analytical processing. This paper presents the approach applying location intelligence as a tool that allows using geospatial analysis algorithms and geovisualization of its results. Due to the extremely large amount of data and the dependence of the results on their accuracy and the level of aggregation, the initial methodology of the analytical process implied two steps: wide scale mapping by the "top down" method, and local mapping by "bottom up" method. However, in order to overcome the problem of regional disparities of quality and the existence of spatial data, certain adaptations of the initial methodology have been made considering the need for a single analytical approach for the entire area of interest. Randomized control of the obtained results indicate that applied geospatial algorithms satisfy the required level of accuracy and reliability of the final methodology.
\end{abstract}

\section{INTRODUCTION}

$\mathrm{I}^{\mathrm{N}}$ N 2004, the European Parliament and the Council of the European Union adopted the Directive 2004/8 EC whose purpose is to increase energy efficiency and develop high efficiency cogeneration of heat and power. The Annex III of the Directive defines the "High Efficiency Cogeneration" as the cogeneration production from cogeneration units that provides primary energy savings (PES) at least $10 \%$ compared with the references for separate production of heat and electricity (small scale cogeneration units, installed capacity below $1 \mathrm{MWe}$, and micro cogeneration units, installed capacity below $50 \mathrm{kWe}$, must provide primary energy savings, that is PES $>0$ ). Bosnia and Herzegovina $(\mathrm{BiH})$ signed the Treaty establishing the Energy Community calling for the adoption and implementation of Acquis Communautaire on energy, environment, competition and renewables. The Acquis' essential directives pre-stipulate the area of energy end-use efficiency and energy services, energy performance of buildings and labelling. Bosnia and Herzegovina also signed to fulfill the obligations under the latest EED directive 2012/27EU [1] including the need to adopt policies incorporating local and regional potentials for using efficient heating and cooling systems, in particular those using high-efficiency cogeneration and the potential for developing local and regional heat markets. According to the directive each country shall carry out a comprehensive assessment of the potential for the application of highefficiency cogeneration and efficient district heating and cooling. The assessment covers entire territory of the country taking into account its specificities like present situation with central heating and cogeneration systems, climate conditions, economic feasibility and technical suitability on potentials for the application of high-efficiency cogeneration and efficient district heating and cooling. The analysis used in the assessment facilitate the identification of the most resource-and cost-efficient solutions to meeting heating and cooling needs [2]. This type of analysis has already been to some extent implemented within the European Union through, for example, the Multi-level Actions for enhanced Heating \& Cooling Plans (STRATEGO) projects funded through the Intelligent Energy Europe [3] and Heat Roadmap Europe (HRE) [4].

Within the technical assistance provided by GIZ $\mathrm{BiH}$ (Deutsche Gesellschaft für Internationale Zusammenarbeit), it was carried out the study by a consultant group which, as part of the assessment, resulted in a mapping approach using geoinformation system (GIS) tools for presentation demands and potentials of using thermal energy.

This paper describes the methodology and the approach applying location intelligence (LI) as a tool that allows using geospatial analysis algorithms and geovisualization of consumption of thermal energy and the potential for the application of high-efficiency cogeneration and efficient district heating and cooling.

\section{THE METHODOLOGY AND THE MAPPING APPROACH}

In order to properly assess the potential for the utilization of highly efficient heating and cooling technologies, primarily district systems and renewables, the spatial distribution of the demand and potential supply must be analyzed. Such an assessment demands a great deal of data which is often not available or at least not public or in a usable format. To work around most of these issues a two- 
step approach is suggested here. In the initial step, the annual heat demand gathered on a national, regional or municipal level will be distributed spatially according to parameters such as population or building density. This will be used to perform a rough estimate to determine which areas are deserving of a more detailed analysis based on heat demand density and/or availability of local renewable resources. The second step will focus on the areas which have demonstrated a high potential for the utilization of highly efficient heating and cooling technologies either because of a high demand density or due to the abundance of renewable energy sources $[5]$.

\section{A. Step one - top down analysis}

As it has been mentioned above, the initial mapping step will be conducted with a top down approach. Annual heating and cooling demand data will be gathered on national, regional and municipal levels (the availability and quality of data will determine the aggregation level). The collected data will be spatially distributed according to parameters such as population densities and land coverage. These data can be found in georeferenced forms in population and building censuses, cadasters and public databases such as the CORINE land use map [6]. The resolutions of these data are varied from very precise such as individual buildings or raster of 100 by 100 meters to less precise ones such as municipal or county level. The end result of this step will be a heating and cooling demand GIS map with a resolution of at least 1 by $1 \mathrm{~km}$. Additionally to the demand, potential supply sources will also be analysed here. Potential heat sources such as excess industry heat, solar and geothermal energy as well as waste will be evaluated and presented in a GIS form. This analysis will provide the possibility to preform and initial evaluation of areas suitable for the exploitation of highly efficient heating and cooling technologies. Areas deemed worthy of further, more detailed, evaluation will be processed in the second step. This will include mostly larger cities and areas close to industrial parks and sources of renewable heat [5].

\section{B. Step two - bottom up analysis}

Areas identified as worthy of further evaluation will be analysed in more details in the second step. Here, a bottom up analysis will be implemented where the scale of the analysis will be individual buildings. For this purpose, cadaster data will be utilized to identify the locations of buildings and other vital data, where available, such as area, volume, age, use, level and time of refurbishment and so on. Representative buildings will be used or modelled to calculate the specific heating and cooling demands for certain building types based on parameters such as use, age and level of refurbishment. This will result in demands per area which will then be used to calculate the heating and cooling demand of all observed buildings. Where digital cadaster data is not available the CORINE land use map will be used and the process will result in a 100 by 100 meter map of the area. Additionally, existing district heating infrastructure will be mapped. This will include production facilities and distribution grids. The resulting map will include the heating and cooling demands, existing infrastructure and potential sources of local renewable and excess heat [5].

Heating and cooling demands represent value (heat) energy required by population for heating and cooling buildings and spaces inhabited.

\section{The mapping approach}

The analysis of this type requires an extremely large amount of data, and the results depend on their accuracy and aggregation level. The methodology described above consists of two steps: state mapping by the "top down" method, and local mapping by "bottom up" method.

The first step of this process allows the development of a coherent map of demand for heating and cooling and potential sources of waste heat for the entire observed area of Bosnia and Herzegovina, its entities of the Federation of Bosnia and Herzegovina (FBiH), Republika Srpska (RS), and Brcko District (DB). The results obtained should serve to determine the priority areas for further analysis in the second step, which is based on a detailed analysis of demand at the level of individual facilities. This would provide detailed maps for areas of potential interest for the exploitation of district heating and cooling systems and high efficiency cogeneration which represented an important source of data for all further analyzes.

This approach would first result in a state map in resolution of $1 \mathrm{x} 1 \mathrm{~km}$, and as a final result, it would be obtained a set of maps with priority areas in 100x100 meter resolution.

Generally, this concept implies the approach applying location intelligence as a tool that allows using geospatial analysis algorithms and geovisualization of its results. In order to realize it may require the application of various tools, spatial data integration procedures [7], types of analysis such as geometric, topological, set oriented, grid and graph analytic methods [8][9].

\section{Geospatial ANAlysis of COGENERATED HeAting POTENTIAL DATA}

In many instances the process of spatial analysis follows a number of well-defined (often iterative) stages: problem formulation; planning; data gathering; exploratory analysis; hypothesis formulation; modeling and testing; consultation and review; and ultimately final reporting and/or implementation of the findings. GIS and related software tools that perform analytical functions only address the middle sections of this process [10].

In this study, the first two stages related to problem formulation and planning are defined by a project assignment, so that the issues of the available data, the 
TABLE I.

LISTS OF DATA SETS USED FOR TOP DOWN AND BOTTOM UP ANALYSIS

\begin{tabular}{|c|c|c|c|}
\hline Data set & Resolution & $\begin{array}{c}\text { Time } \\
\text { reference }\end{array}$ & Source \\
\hline $\begin{array}{l}\text { Census data / } \\
\text { population }\end{array}$ & $\begin{array}{l}\text { Enumeration } \\
\text { area }\end{array}$ & 2013 & $\begin{array}{l}\text { Institutes for } \\
\text { statistics in } \mathrm{BiH}\end{array}$ \\
\hline $\begin{array}{l}\text { Census data / } \\
\text { housing }\end{array}$ & $\begin{array}{l}\text { Enumeration } \\
\text { area }\end{array}$ & 2013 & $\begin{array}{l}\text { Institutes for } \\
\text { statistics in } \mathrm{BiH}\end{array}$ \\
\hline $\begin{array}{l}\text { Climate zone / } \\
\text { polygons }\end{array}$ & Country & 2018 & $\begin{array}{l}\text { Meteorological } \\
\text { institutes in } \mathrm{BiH}\end{array}$ \\
\hline $\begin{array}{l}\text { Enumeration } \\
\text { areas / polygons }\end{array}$ & $\begin{array}{l}\text { Approx. } 100 \\
\text { by } 100 \mathrm{~m}\end{array}$ & 2013 & $\begin{array}{l}\text { Institutes for } \\
\text { statistics in } \mathrm{BiH}\end{array}$ \\
\hline $\begin{array}{l}\text { Municipal } \\
\text { boundaries }\end{array}$ & $\begin{array}{l}\text { Cadaster } \\
\text { municipality }\end{array}$ & 2018 & $\begin{array}{l}\text { Geodetic } \\
\text { administration of } \\
\text { BiH entities }\end{array}$ \\
\hline $\begin{array}{l}\text { Cadastral data / } \\
\text { buildings }\end{array}$ & $\begin{array}{l}\text { Cadaster } \\
\text { parcel }\end{array}$ & 2018 & $\begin{array}{l}\text { Geodetic } \\
\text { administration of } \\
\text { BiH entities }\end{array}$ \\
\hline $\begin{array}{l}\text { CORINE Land } \\
\text { Cover }\end{array}$ & 25 ha & 2012 & $\begin{array}{l}\text { European } \\
\text { Environment } \\
\text { Agency }\end{array}$ \\
\hline $\begin{array}{l}\text { OpenStreet } \\
\text { Map }\end{array}$ & - & 2018 & OS data \\
\hline $\begin{array}{l}\text { Sources of waste } \\
\text { heat / points }\end{array}$ & - & 2018 & $\begin{array}{l}\text { Institutes for } \\
\text { spatial planning } \\
\text { in } \mathrm{BiH}\end{array}$ \\
\hline $\begin{array}{l}\text { Industrial } \\
\text { facilities / points }\end{array}$ & - & 2018 & $\begin{array}{l}\text { Institutes for } \\
\text { spatial planning } \\
\text { in } \mathrm{BiH}\end{array}$ \\
\hline $\begin{array}{l}\text { Greenhouse gas } \\
\text { emissions }\end{array}$ & - & 2016 & $\begin{array}{l}\text { Third national } \\
\text { communication } \\
\text { report on } \\
\text { greenhouse gas } \\
\text { emissions of } \mathrm{BiH}\end{array}$ \\
\hline $\begin{array}{l}\text { Orthophoto } \\
\text { maps }\end{array}$ & $\begin{array}{l}\text { Scale } 1: 2500 \\
/ 1: 5000\end{array}$ & 2012 & $\begin{array}{l}\text { Geodetic } \\
\text { administration of } \\
\text { BiH entities }\end{array}$ \\
\hline $\begin{array}{l}\text { District Heating } \\
\text { Systems } \\
\text { Infrastructure }\end{array}$ & $\begin{array}{l}\text { Cadaster of } \\
\text { infrastructure } \\
\text { facilities }\end{array}$ & 2018 & $\begin{array}{l}\text { District heating } \\
\text { companies in } \mathrm{BiH}\end{array}$ \\
\hline $\begin{array}{l}\text { Meteorological } \\
\text { data }\end{array}$ & Municipality & 2018 & $\begin{array}{l}\text { Meteorological } \\
\text { institutes in } \mathrm{BiH}\end{array}$ \\
\hline
\end{tabular}

analytical process itself, and the testing of the applied model, ie control of the results are outlined below. The quality and completeness of the data can have a dramatic impact and can cause implications for the results and the process of spatial data analysis itself [11]. During the geospatial analysis it was concluded that the sets of available data were not enough to carry out the analysis according to the initial methodology, and its adaptation was proposed. Also, a brief overview of the results of the analysis has been described, showing how well adapted the methodology is acceptable for further application.

\section{A. Available data}

The major challenge for the design of the heating potential assessment study was the availability and quality of input data in various formats and for various purposes. For the purpose of providing data for calculating the needs for heating and cooling, various data sources have been used: land cadaster, population census, weather statistics, geodetic surveys, administrative statistical spatial boundaries, address register, map data (climate, rainfall, soil, forest cover), land use and land cover data CORINE 2012, official ortophotos, DEM, LiDAR, and public information on the Internet, such as studies on construction types, remote heating, energy efficiency, climate change and other sources related to the $\mathrm{BH}$ area. Useful sources were also typologies of residential and public buildings in $\mathrm{BiH}$ [12][13], as well as cogenerate sources and waste material co-incineration data [14].

Among the most important available data sets are the census data related to housing units, the way of heating and energy consumption. Some of the attributes associated with these sets were: the area of the apartment, the type of heating, the type of building, the year of construction, the number of floors, the building material, the building structure and the state of the object. Also, data for all existing district heating systems in $\mathrm{BiH}$ are collected.

Further, various data was collected for the needs of determining the specific annual heat energy required for heating and the annual cooling energy required per sector, which includes: altitude for municipalities, external temperature for building design, degree of development of municipalities, number of inhabitants per municipality, number of employees per sector, number households by municipalities, average household size per municipality, and total average residential area (usable area) per capita. Table I lists some of the spatial data sets used for the analysis.

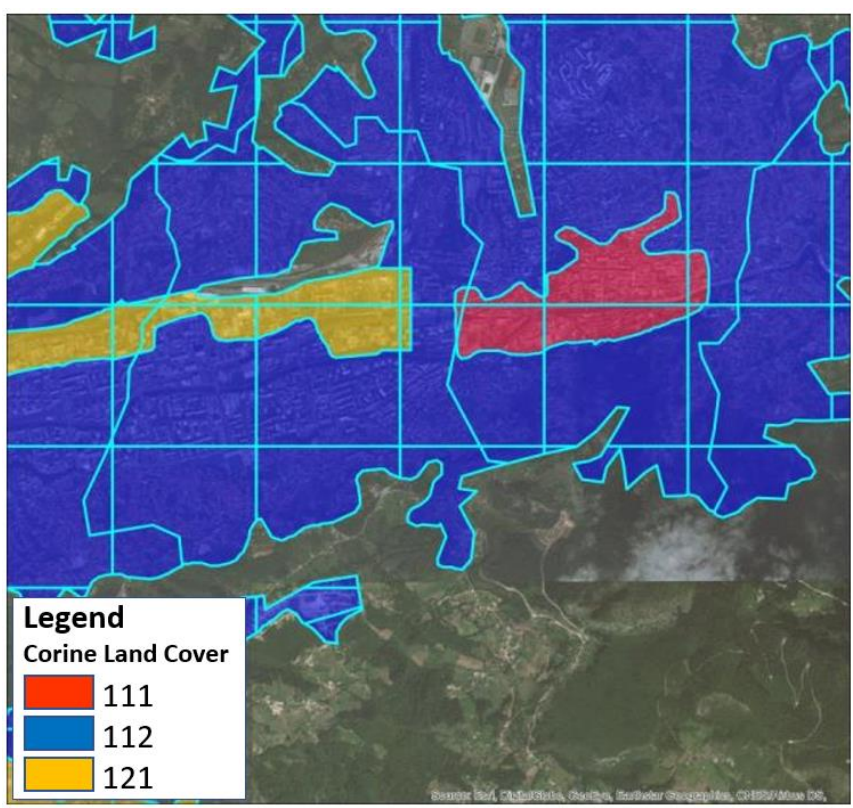

Figure 1. Intersection network, municipality boundaries and CLC data sets 
B. Geospatial analysis of heating potential data and adaptation of the methodology

In order to fully apply the described methodology, in addition the aforementioned sets, many more data were needed, but some were not available in useful form. Particular problems were the lack of geometric data on residential and industrial buildings in some parts of the country, as well as topological defects related to polygons of statistical units, which are used for the intersection with the network of squares for the presentation of the heating demands. Also, the lack of comprehensive and consistent data for the non-residential sector in $\mathrm{BiH}$ was particularly evident.

In order to overcome all the problems of regional disparities of quality and the existence of spatial data, certain adaptations of the initial methodology have been made considering the need for a single analytical approach for the entire area of interest.

\section{1) Country level mapping by the "top down" method}

One of the aspects of this analysis was the determination of heating and cooling needs at the national and local level. In the first phase (top down) is made calculation of energy needs on state level for the following sectors: housing, public and service sector, and industry (Figure 2).

The procedure is based on determining the total area of housing, the public and service sectors, and the industry sector (in $\mathrm{km} 2$ ). This activity was carried out using the CORINE database, that is CORINE Land Cover (CLC), where are filtered only the categories of land cover which exclusively belonging to the one of the following classes:

- Continuous urban fabric (CLC code 1.1.1),

- Discontinuous urban fabric (CLC code 1.1.2.),

- Industrial or commercial units (CLC code 1.2.1).

The processing continued to provide information on how
Top down analysis

\begin{tabular}{|c|c|}
\hline $\begin{array}{l}\text { Determination of heating } \\
\text { and cooling needs at the } \\
\text { national and local level }\end{array}$ & $\begin{array}{l}\text { Determiniation the total area of } \\
\text { housing, public and service } \\
\text { sectors, and the industry sector }\end{array}$ \\
\hline & 1 \\
\hline \multicolumn{2}{|c|}{$\begin{array}{l}\text { Spatially distribution of annual heating and cooling data according } \\
\text { to population density (from census data) and land coverage (from } \\
\text { CORINE land use map) }\end{array}$} \\
\hline \\
\hline \multicolumn{2}{|c|}{ Heating and cooling demand mapping with resolution 1 by $1 \mathrm{~km}$} \\
\hline & \\
\hline \multicolumn{2}{|c|}{$\begin{array}{l}\text { Potential supply sources analysis with circular buffer of } 20 \mathrm{~km} \\
\text { diameter }\end{array}$} \\
\hline \multicolumn{2}{|c|}{$\nabla$} \\
\hline \multicolumn{2}{|c|}{$\begin{array}{l}\text { Identification areas for detailed (bottom up) analysis according to: } \\
\text { - potential heat sources proximity } \\
\text { - existing remote heating system (RHS) infrastructure and } \\
\text { - density of the heat needs. }\end{array}$} \\
\hline
\end{tabular}

Figure 2. Steps of top down analysis

many municipalities have certain categories of land (in $\mathrm{km} 2$ ). Further, the same information is displayed spatially by a $1 \mathrm{x} 1$ $\mathrm{km}$ resolution raster. By addressing these data with data on energy needs calculation, final data was obtained at the municipal level and at the level of each square $(1 \times 1 \mathrm{~km})$.

For this purpose, it was necessary to perform several operations in the GIS to enable the correct spatial distribution of the energy demand data. The first step involved intersecting three sets of data:

- Corina Land Cover (CLC) with

- $1 \mathrm{x} 1 \mathrm{~km}$ network; and

- the boundaries of the municipalities.

Figure 1 gives the example of the data intersection. In this way, they are determined the area of each particle obtained, its belonging to the certain municipality and square of the

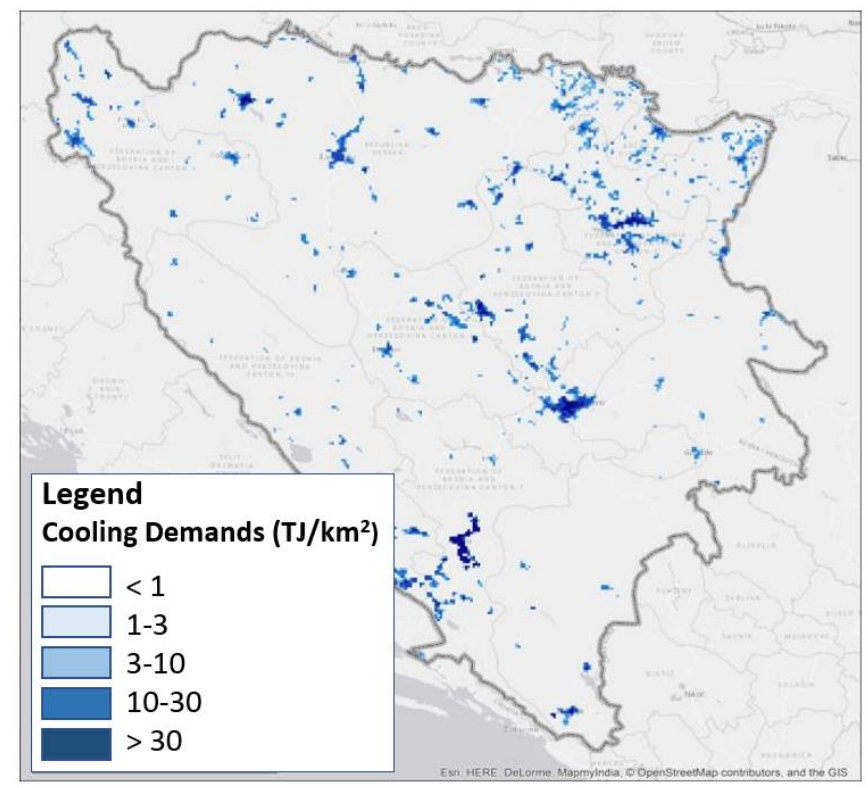

Figure 3. Maps of heating (left side) and cooling demands (right side) in Bosnia and Herzegovina with values in MWh/km2 and TJ/ km2 units per year 
network, and then heating and cooling demand are allocated to each particle.

Also, percentage share $(\%)$ of each particle in total area of a given municipality is determined for each purpose. The required annual heating energy for residential, public and service sector $\left(R E D_{p R / P S}\right)$ is calculated using the formula (1):

$$
R E D_{p R / P S}=\frac{A_{p i}}{A_{\text {in }}} \times R E D_{n R / P S}
$$

where are:

- $A_{p i}$ area of the particle , $p$ “ with purpose , ,i“;

- $A_{\text {in }}$ total area of land belonging to CLC class for purpose,$i “$ in certain municipality,$n$ ";

- $R E D_{n R / P S}$ required heating energy in municipality ,,$n^{\prime \prime}$ for residental, public and service sector.

In this way, the required heating energy for the industry sector is also determined $\left(R E D_{p I}\right)$.

The total required heating energy at the level of each square should correspond to the sum of the individual needs of each respective particle for the different purposes of the CLC class land.

The same principle was used to determine the required cooling energy.

The applied methodology resulted in distribution of heating and cooling requirements at the level of the network square $(1 \mathrm{~km} 2)$ for the country. Due to a clearer view, two types of maps were created (Figure 2). with different measuring units (in $\mathrm{MWh} / \mathrm{km}^{2}$ and in $\mathrm{TJ} / \mathrm{km}^{2}$ yearly).

Figure 3 Maps of heating (left side) and cooling demands (right side) in Bosnia and Herzegovina with values in $\mathrm{MWh} / \mathrm{km}^{2}$ and $\mathrm{TJ} / \mathrm{km}^{2}$ units per year

For the purpose of allocating potential sources of waste heat, 21 sources, which are mainly large industrial and energy facilities (Figure 4), are identified and mapped. Currently, much of the surplus energy from these plants,

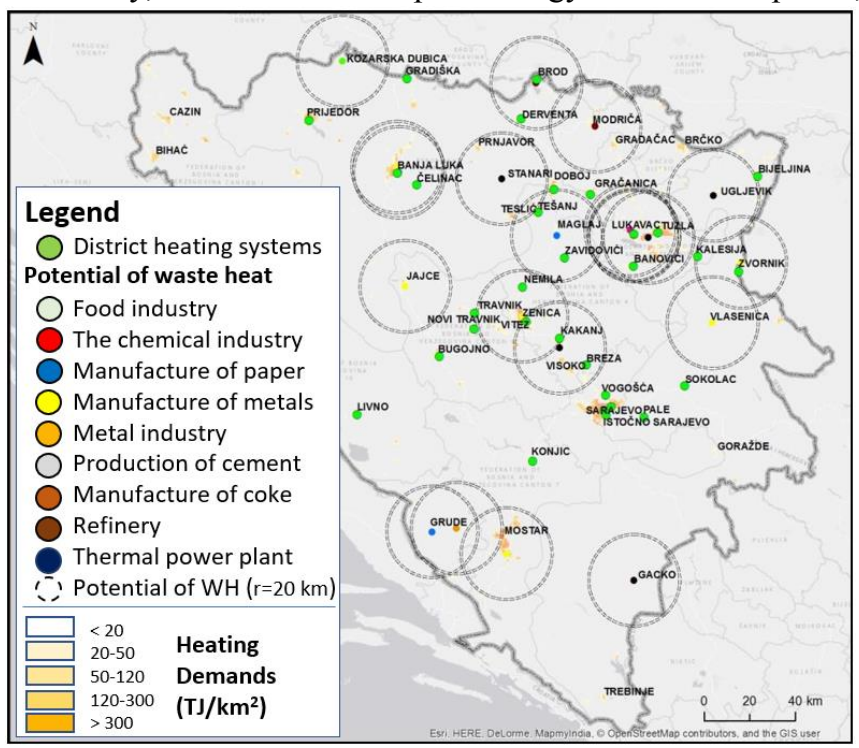

Figure 4. An overview of heating needs $(\mathrm{TJ} / \mathrm{km} 2)$ and waste heat potential which can be used for heating and cooling purposes, remains unused, although these plants are mostly situated near densely populated settlements. The heat surplus from these plants can be theoretically estimated based on primary energy consumption or $\mathrm{CO}_{2}$ emissions. A detailed description of the methodology for calculating the waste heat from CO2 emissions can be found in the STRATEGO [15] report and research works [16].

For the purposes of assessing the potentials of high efficiency cogeneration in $\mathrm{BiH}$, it is made the selection of areas which have relatively high density of heating needs, and these are mostly urban parts of municipalities and cities.

2) Local level mapping by the " bottom up " method

The second step relates to the mapping of heating and cooling demands at the local level for every selected area (municipality or city). Similarly, to the first step of the mapping (top down), the calculation for energy needs at the level of individual municipalities has been implemented separately for housing, public and services sector and for industry sector (Figure 5).

For selection of municipalities and cities, the following criteria were applied:

- existing remote heating system (RHS) infrastructure,

- proximity of the waste heat potential and

- the density of the heat needs.

The illustration of these data is shown in Figure 4.

According to the first and key criterion it is needed to select the urban environment with existing remote heating. The second criterion is the potential for exploitation of waste heat from industrial plants, as waste heat is the most convenient source for remote heating. A radius of $20 \mathrm{~km}$ has been set for areas with potential for waste heat utilization. The third criterion is the density of energy needs that goes to

\section{Bottom up analysis}

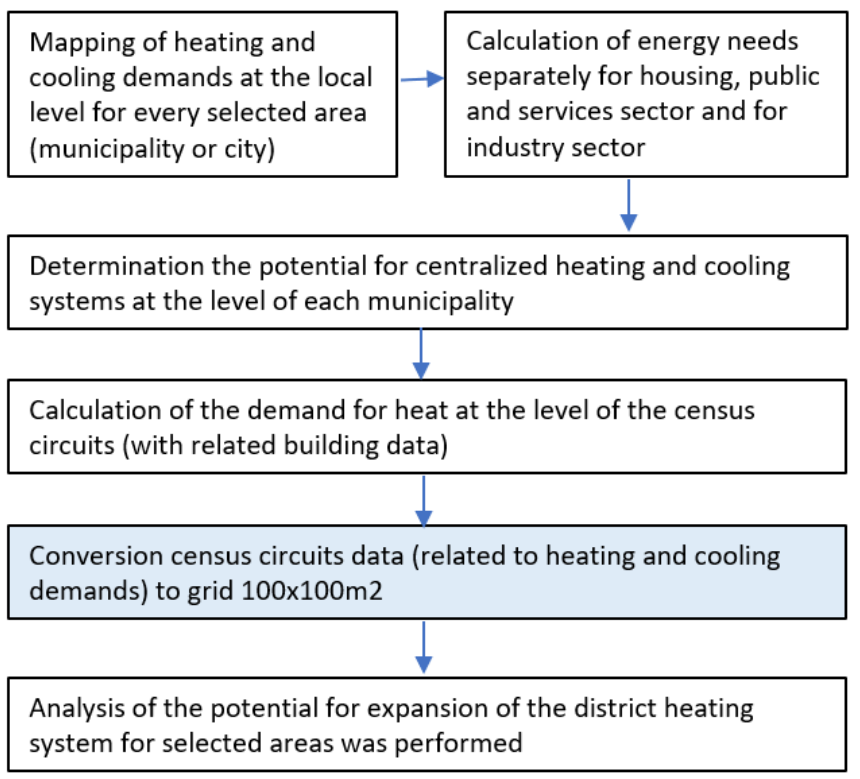

Figure 5. Steps of bottom up analysis 
favor of those urban environments that do not have existing district heating and are not close to an industrial plant with waste heat but can justify investment because of high demands.

Taking into account the aforementioned criteria, a total of 39 cities and municipalities have been selected for further analysis, representing over $60 \%$ of total heating needs and $55 \%$ of cooling demand in Bosnia and Herzegovina.

According to the adopted methodology, heat energy needs for selected areas are determined for the residential and nonresidential sector separately, and the results are presented on maps by network in resolution $100 \times 100 \mathrm{~m}$ (Figure 6a).

In the final part of the study, it was determined the potential for centralized heating and cooling systems at the level of each municipality. Also, the analysis of the potential for expansion of the district heating system for selected areas was performed (Figure 6b). In discussion section of this paper, the deficiencies related to the application of the methodology are explained.

\section{Control of results}

By visual detection, it is obvious that heating and cooling demands are distributed in terms of expectations and according to the areas where the largest number of inhabitants is concentrated (population per $\mathrm{km} 2$ ) and depending of geographic and climatic characteristics. In order to validate the data, it is conducted a detailed analysis of the municipalities of the City of Sarajevo (Figure 7) as well as several other municipalities, using information and experience gained through work on previous similar projects.

Based on the data presented in Figure 7, it can be concluded that the data spatial distribution satisfies, and the data are geocoded in accordance with the expectations and the real situation. The figures in the quadrants indicate heating demands in MWh / km2. The areas of the Novi Grad municipality (Figure 6a), namely the settlements Alipasino Polje, Hrasno and Cengic Vila indicate the high demand in this case as in the reality. On the other hand, the values

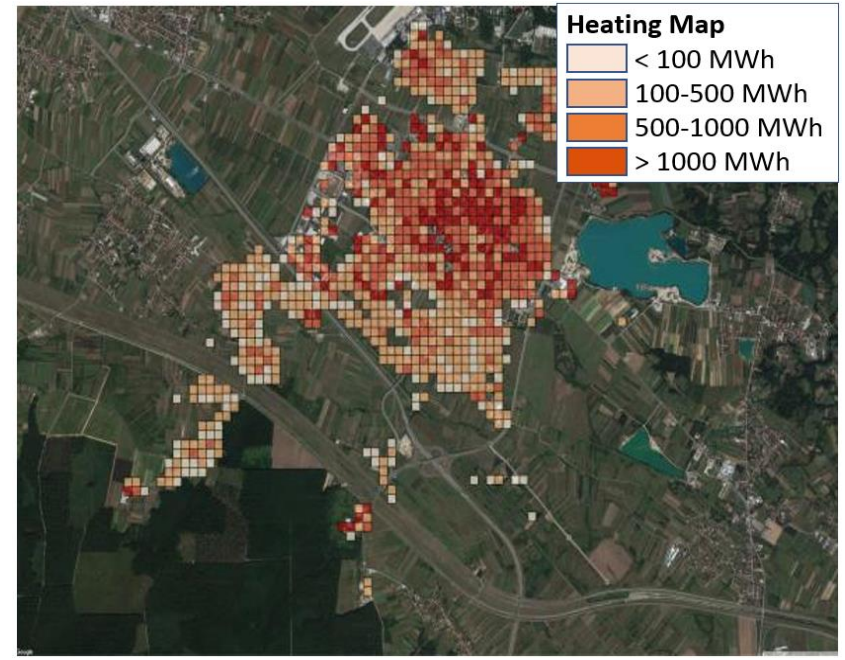

related to the peripheral parts of the city in Figure $6 \mathrm{~b}$, due to the smaller population density and the construction of individual residential buildings, indicate less heating needs. It can be concluded that the data is logically distributed in the space. For the purpose of final validation, a detailed analysis of the values based on their random selection was performed in accordance with the statistics norms.

For validation purposes, these results are also compared to other available data. For example, in the UK value of the largest demand quadrant is over $200,000 \mathrm{MWh}$, while in $\mathrm{BiH}$ it is close to $90.00 \mathrm{MWh}$. Considering the urbanization and population density (e.g. population density in the urban area of London is 1.65 times higher than in the urban area of Sarajevo), the data obtained can be considered as credible. Analyzing the available data from other countries in Europe (Spain, Czech Republic, Poland, Luxembourg), the results satisfy the expected framework (by the benchmark analysis).

\section{DISCUSSION}

Location intelligence (LI) implies an insight into the geospatial relationships between the phenomena that are studied to solve the problem important for spatial decision making [17]-[ 21]. This allows a layered spatial display of data sets processed using GIS tools for their transformation, analysis, and visualization.

In this study, LI had a twofold role:

- to prepare the cartographic basis for complex spatial analysis

- to visualize the spatial distribution of demands and potentials for the use of heat energy from cogeneration.

During the processing of geometric and attribute data in GIS special challenge was the heterogeneity of data (both syntax and semantic) [22] [23]. Namely, part of the accessible data represented attribute dwelling data referenced by census numbers and geometric data (polygons) of census circles that came from different sources. Due to its consistency and the unique model, it has been suggested to

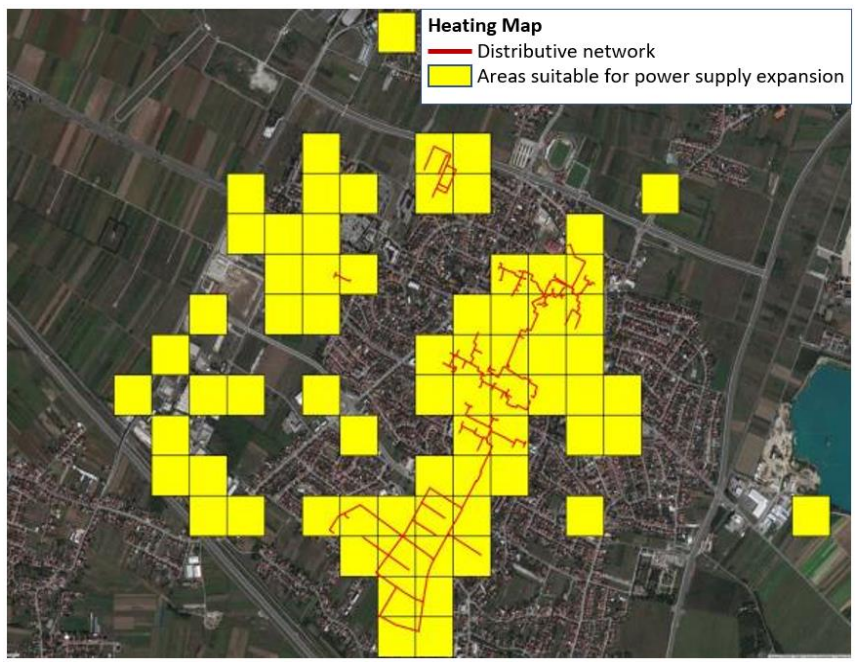

Figure 6. Examples of maps: a) heating demands presented by network $100 \times 100 \mathrm{~m}$ (left side) and b) potential for expansion of remote heating system (right side) 


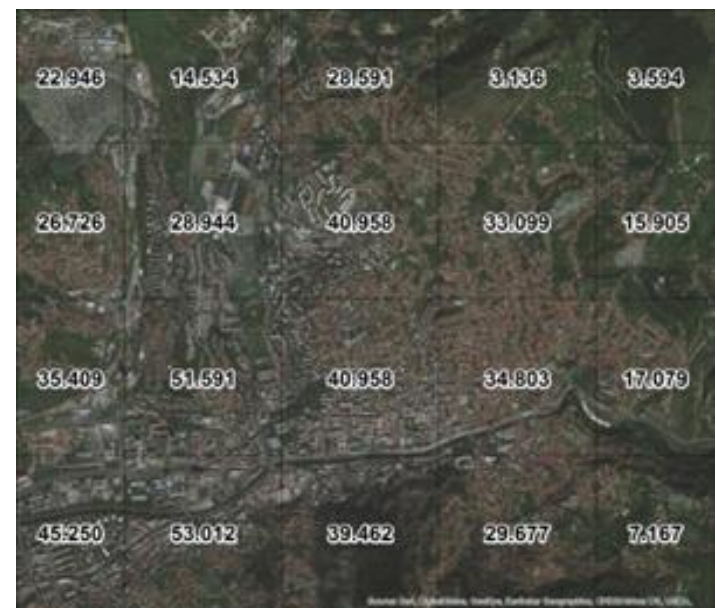

Figure 7. Heating demands in $\mathrm{MWh} / \mathrm{km} 2$ at $100 \times 100 \mathrm{~m}$ network level in the City of Sarajevo, municipalities of Centar and Stari Grad

apply these data for the whole $\mathrm{BiH}$ area. Thus, they were used as a basis for the overall analysis, including the calculation of the demand for heat at the level of the census circuits.

Certain geometric data sets (for example, Brcko District) did not meet the topological conditions, so their further processing was done, including topology control, polygonization, and redrawing.

Further, the data on spatial content objects intended for commercial and other non-residential needs were not available for the whole area of interest, so that the following situations were evident for certain municipalities:

- partial or complete lack of data on buildings

- different formats and ways of layer presentation

- incompleteness of the data, including census numbers, inability to connect geometry with attribute data and other problems.

Also, no data on the district heating distribution network was available for a number of municipalities.

Because of these reasons different approaches have been used to compensate these shortcomings. For most of the municipality, data on buildings is downloaded from the Internet (Open Source Maps) and data are formatted to a unique format for applying a uniform GIS processing model. For some municipalities, it was not possible to determine the demands of the non-residential sector due to lack of data on buildings. Most of the data is taken from the cadaster databases resulting in the lack of many buildings and the unreliability of their areas due to timeliness.

After determining the key indicators of the situation with the energy needs, it is followed their geovisualization and creating of intelligent maps with different thematic levels (by point symbols, by municipalities, by grids $1 \times 1 \mathrm{~km}$ and 100x100 m resolution). This implied the creation of several maps of heating demands (Figure 8), cooling demands (Figure 9), the potential of waste heat, the potential of renewable energy sources including solar energy, biomass, geothermal energy, and finally maps of existing district heating systems and the potential of their expansion. For the

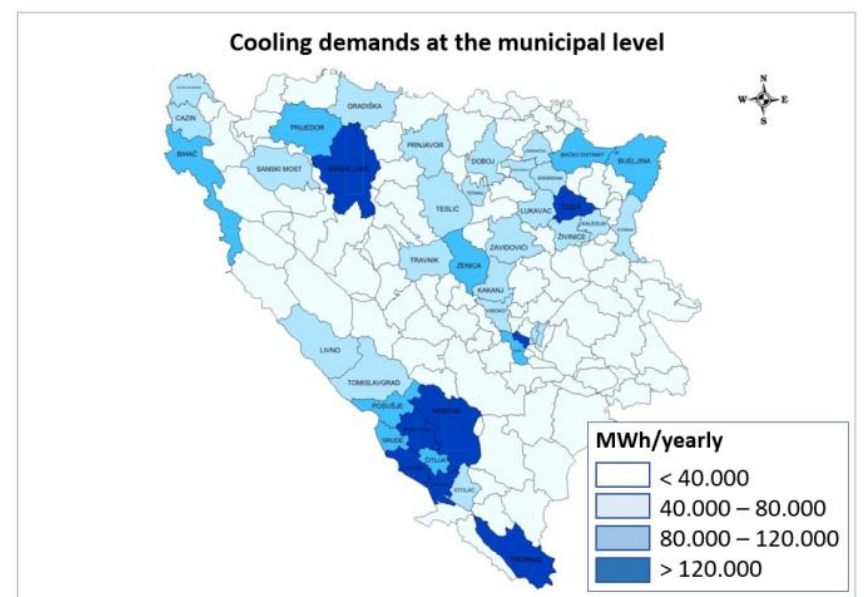

Figure 8. Map of cooling demands distribution by municipalities purposes of map creation, the appropriate models and designing procedures for each type of map were prepared followed by an appropriate set of data from the database.

For the purposes of mapping "top down", ie the determination of priority areas for further analysis, statistical data was collected at the level of individual municipalities. These data included the population, the total areas of all types of building and the climatic zones. Using these data and calculating the specific demand for heating and cooling for particular types of objects, demand for heating and cooling of each municipality was determined. These data were then distributed spatially by the CORINE map. Sources of waste heat and the potential amounts of energy they can deliver to the system are determined through collected data on greenhouse gas emissions according to the proposed methodology. The "top down" methodology used in this case was fully applied and no significant deviations were noted.

However, due to the lack of some key data needed to conduct „,bottom-up“ analysis, the initial methodology had to be partially adapted. As cadastral data was not available for all the observed municipalities, and for some missing significant amounts of data, the application of Open Source Maps data was suggested, but this source was again insufficiently detailed. Data on the altitudes and the building purpose were also not available in a large part of the

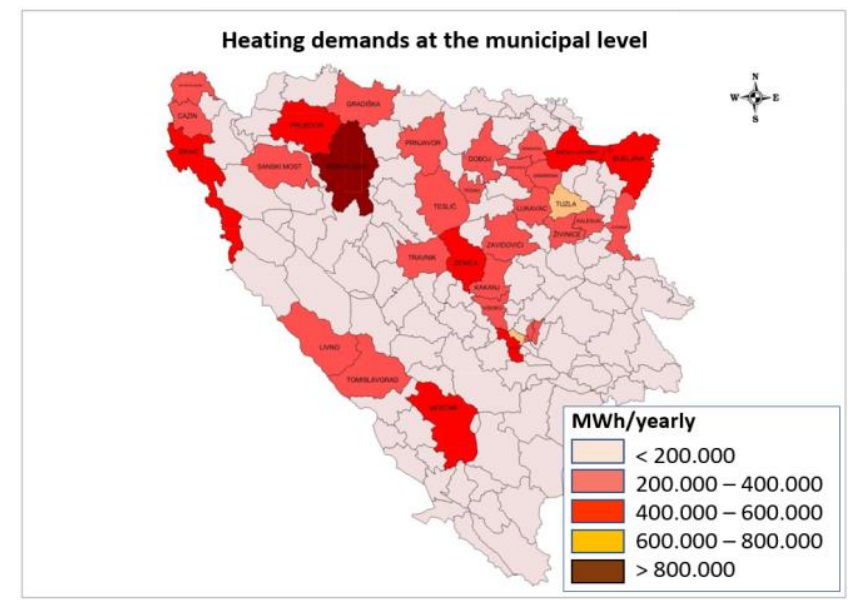

Figure 9. Map of heating demands distribution by municipalities 
municipalities because they were either not public or not at all. Analyzing literature, it looks that are all common problems of similar projects. [24] [25]

In order to achieve the required goals, data at the level of census circles (which areas are mainly below $100 \times 100 \mathrm{~m}$ ) is applied, which gave results of comparable quality.

The proposed methodology could not be fully realized in this case due to the lack of key data, but the proposed alternatives are acceptable and have achieved satisfactory quality and level of detail.

\section{V.CONCLUSION}

In order to ensure the successful implementation of a comprehensive assessment of the potential for high efficiency cogeneration and efficient centralized heating and cooling, it is necessary to know the spatial distribution of their demand as well as potential sources of waste heat. Since the process of such mapping is highly dependent on the availability of data, it is initially proposed two step approach including methods of state mapping by the "top to bottom" and local mapping by "bottom up". The purpose of such an approach is, on the one hand, to create a coherent map with distributions of demand for heating and cooling and potential sources of waste heat for the whole observed area with a grid in resolution $1 \times 1 \mathrm{~km}$. On other hand, local mapping of selected areas gives a more detailed view of the state by applying a grid in resolution 100x100 meters [5].

For the final procedure applied for the assessment of the potential for the application of high-efficiency cogeneration and efficient district heating and cooling, they are suggested alternatives which were proved as acceptable. The main reason for the deviation from the initial methodology is the lack of data on which the methodology depends. This applies in particular to the data required in the "bottom up" mapping, ie to the current cadastral data on buildings. In order to conduct the process with an adequate level of detail, it is used census circuit data which generally have a resolution of less than 100X100 meters and are therefore applicable for the described procedure. The obtained results are in line with what the default methodology prescribes.

Randomized control of the obtained results indicate that applied data sets and appropriate geospatial algorithms satisfy the required level of accuracy and reliability implied by this methodology.

\section{REFERENCES}

[1] "Energy Efficiency Directive 2012/27/EU", Available: https://eurlex.europa.eu/eli/dir/2012/27/oj [Accessed: 7-Jan-2018]

[2] Final Report on Assessment of the Potential for the Application of High-efficiency Cogeneration and Efficient District Heating and Cooling, Ceteor Sarajevo, 2018

[3] "Stratego." [Online]. Available: http://stratego-project.eu/. [Accessed: 30-Aug-2017]

[4] "Heat Roadmap Evrope." [Online]. Available: http://www.heatroadmap.eu/. [Accessed: 15-Jun-2017]

[5] N. Duic, T. Puksec, and T. Novosel, "Methodology for assessment of the potential for the application of high-efficiency cogeneration and efficient district heating and cooling - Development of state and local GIS maps", Sarajevo, 2018

[6] "CORINE Land Cover - Copernicus Land Monitoring Service." [Online]. Available: https://land.copernicus.eu/pan-evropean/corineland-cover. [Accessed: 10-Jan-2018]

[7] A. Karabegovic, M. Ponjavic, "Integration and Interoperability of Spatial Data in Spatial Decision Support System Environment", MIPRO IEEE Croatia Conference, Opatija, Croatia, 2010

[8] P.Longley, M. Goodchild, D. Maguire, D. Rhind, „Geographic Information Systems and Science“, John Wiley \& Sons, 2002

[9] M.Ponjavic, "Basics of Geoinformation", Faculty of Civil Engineering, University of Sarajevo, 2011

[10] M.de Smith, M.Goodchild, P.Longley,"Geospatial Analysis - A Comprehensive Guide to Principles Techniques and Software Tools, https://www.spatialanalysisonline.com, 2018

[11] R. Haining, "Spatial Data Analysis: Theory and Practice", Cambridge University Press, 2003

[12] D. Arnautović-Aksić et al., Typology of residential buildings of Bosnia and Herzegovina, GIZ Sarajevo, 2016

[13] M. Nisandzic et al., Typology of Public Buildings in Bosnia and Herzegovina, UNDP Sarajevo, 2017

[14] Feasibility Study of Animal By-products and Animal Waste Management in Bosnia and Herzegovina, EPRD Office for Economic Policy and Regional Development Ltd. Poland, 2018

[15] U. Persson, "Quantifying the Excess Heat Available for District Heating in Evrope," p. 17, 2015

[16] U. Persson, B. Moller, and S. Werner, "Heat Roadmap Evrope: Identifying strategic heat synergy regions," Energy Policy, vol. 74, pp. 663-681, 2014

[17] A. Karabegovic and M. Ponjavic, "Geoportal as decision support system with spatial data warehouse," 2012 Federated Conference on Computer Science and Information Systems (FedCSIS), Wroclaw, 2012, pp. 915-918

[18] M. Ponjavic, and A. Karabegovic, "Location Intelligence Systems and Data Integration for Airport Capacities Planning", Computers. 2019; 8(1):13, https://doi.org/10.3390/computers 8010013

[19] V. Somogyi, V. Sebestyén, and E. Domokos, "Assessment of wastewater heat potential for district heating in Hungary", Energy, vol 163, 2018, pp. 712-721, ISSN 0360-5442, https://doi.org/10.1016/j.energy.2018.07.157.

[20] A. Dénarié, M. Muscherà, M. Calderoni, and M. Motta, "Industrial excess heat recovery in district heating: Data assessment methodology and application to a real case study in Milano", Italy, Energy, vol 166, 2019, pp. 170-182, ISSN 0360-5442, https://doi.org/10.1016/j.energy.2018.09.153.

[21] R. Buffat, and M. Raubal, "Spatio-temporal potential of a biogenic micro CHP swarm in Switzerland", Renewable and Sustainable Energy Reviews, vol 103, 2019, pp. 443-454, ISSN 1364-0321, https://doi.org/10.1016/j.rser.2018.12.038.

[22] M. Segal, "Location always matters: how to improve performance of dynamic networks?", 2016 Federated Conference on Computer Science and Information Systems, M. Ganzha, L. Maciaszek, M. Paprzycki (eds). ACSIS, Vol. 8, pp. 5-5, 2016. http://dx.doi.org/10.15439/2016F596

[23] B. Prokop, J. Owsiński, K. Sęp, P. Sapiecha, "Solving the k -Centre Problem as a method for supporting the Park and Ride facilities location decision", 2016 Federated Conference on Computer Science and Information Systems, M. Ganzha, L. Maciaszek, M. Paprzycki (eds). ACSIS, Vol. 8, pages 1223-1228, 2016 http://dx.doi.org/10.15439/2016F300

[24] E. Ziemba, "The ICT Adoption in Government Units in the Context of the Sustainable Information Society", Federated Conference on Computer Science and Information Systems, M. Ganzha, L. Maciaszek, M. Paprzycki (eds). ACSIS, Vol. 15, pp. 725-733, 2018. http://dx.doi.org/10.15439/2018F116

[25] P. Ziemba, J. Wątróbski, A. Karczmarczyk, J. Jankowski, W. Wolski, "Integrated Approach to e-Commerce Websites Evaluation with the Use of Surveys and Eye Tracking Based Experiments", 2017 Federated Conference on Computer Science and Information Systems, M. Ganzha, L. Maciaszek, M. Paprzycki (eds). ACSIS, Vol. 11, pp 1019-1030, 2017. http://dx.doi.org/10.15439/2017F320 